\title{
EFFECT OF ENCASEMENT LENGTH ON GEOSYNTHETIC REINFORCED STONE COLUMNS
}

\author{
Kausar Ali \\ Associate Professor, University Polytechnic, Aligarh Muslim University, U.P, India
}

\begin{abstract}
Being cost effective and environmental friendly, stone columns are used worldwide for supporting flexible structures such as embankments, oil storage tanks etc. which can tolerate some settlements. However, when the stone columns in very soft soils are loaded; stone columns undergo excessive settlement due to low lateral confinement provided by the soft soil, leading to the failure of the structure. The excessive settlements may be avoided or at least reduced to a great extent, when the columns are reinforced with geosynthetic. The technique of wrapping the individual stone column with a suitable geosynthetic (encasement) is one of the reinforcement modes which improve the performance of stone columns. In this study, model tests were performed on single floating as well as end-bearing stone columns with and without encasement. The column was reinforced by providing geosynthetic encasement over varying column length. The tests indicate that the encasement over the full column length gives higher failure stress as compared to the encasement over partial length of column for both floating and end bearing columns. Further, the performance of end-bearing columns was found to be better than the floating columns.
\end{abstract}

Keywords: Geosynthetic, Ground Improvement, Soft Clay, Stone Column.

\section{INTRODUCTION}

Stone columns have been used as an effective technique for improving the engineering behaviour of soft clays and loose sand deposits [1], [2]. It is well established that the stone columns derive their load carrying capacity from the lateral earth pressure against bulging from the surrounding soils [3]. When the stone columns are installed in extremely soft soils, the lateral confinement offered by the surrounding soil may not be adequate. Consequently, the stone columns installed in such soils will not be able to develop the required load-bearing capacity. In such situations, the bearing capacity of composite ground can be improved by imparting additional confinement to the stone column by encasing the individual stone columns using a geosynthetic. The behaviour of reinforced stone columns has studied by [4] - [6]. Most of the work done so far is limited to fully penetrating columns; therefore, in this study model tests have been carried out on fully penetrating as well as floating columns. Further, there is dearth of literature related to partial encasement of stone columns. Therefore, this study also consists of model tests performed for various percentages of encasement lengths.

\section{MATERIALS AND METHODS}

\subsection{Materials, Instrumentation and Test}

The model tests were conducted on soft soil bed reinforced with stone columns. The soft soil bed was made up of fully saturated remolded kaolin clay. The properties of the kaolin clay are given in Table 1 . The columns were made up of stone chips of size varying from $2 \mathrm{~mm}$ to $4.75 \mathrm{~mm}$ compacted at a relative density of $60 \%$ and having an angle of internal friction $\phi=45^{\circ}$ as determined by the direct shear test. A $20 \mathrm{~mm}$ thick mat of sieved Badarpur sand was provided below the footing area in all model tests. The sand passed through $1 \mathrm{~mm}$ sieve and retained on 600 micron sieve having an internal friction angle $\phi=38^{\circ}$ was used for this purpose. The grain size distribution of kaolin clay, Badarpur sand and stone chips is shown in Fig. 1. A woven geotextile of tensile modulus $=98 \mathrm{kN} / \mathrm{m}$ was used to reinforce the model stone columns as encasement.

Table -1: Properties of the clay used in the model tests

\begin{tabular}{|l|l|}
\hline Parameter & Value \\
\hline Specific Gravity & 2.64 \\
\hline Liquid Limit (\%) & 54 \\
\hline Plastic Limit (\%) & 23 \\
\hline Plasticity Index (\%) & 31 \\
\hline Saturated unit weight $\left(\mathrm{kN} / \mathrm{m}^{3}\right)$ & 18.59 \\
\hline Dry unit weight $\left(\mathrm{kN} / \mathrm{m}^{3}\right)$ & 14.5 \\
\hline Water content $(\%)$ & $40 \pm 1$ \\
\hline Shear strength $(\mathrm{kPa})$ & $6-7$ \\
\hline Clay $(\%)$ & 55 \\
\hline Silt $(\%)$ & 35 \\
\hline
\end{tabular}




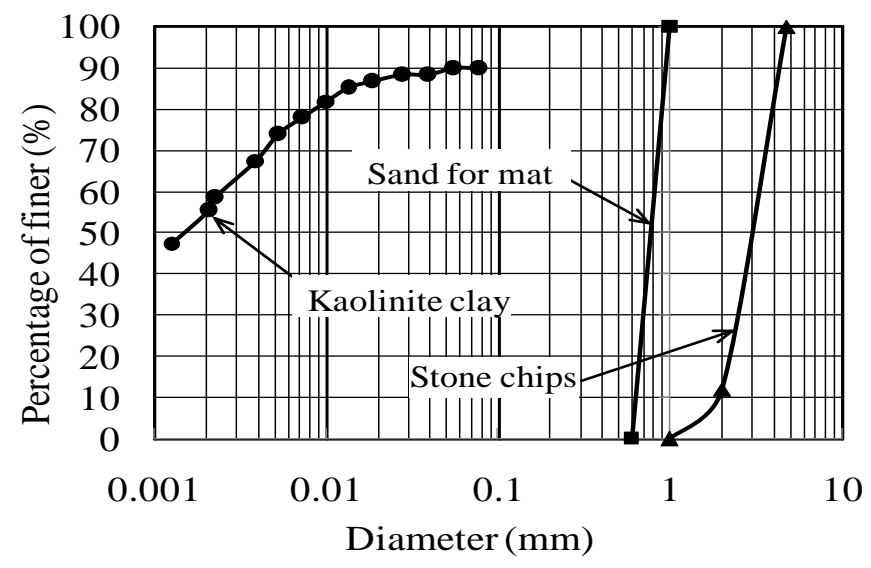

Fig 1: Grain size distribution of kaolin, sand and stone chips

All tests on floating column models were performed in a steel tank of $400 \mathrm{~mm}$ internal diameter, $700 \mathrm{~mm}$ depth and 5 mm wall thickness (Fig. 2). All tests on end-bearing column models were performed in a steel tank of $400 \mathrm{~mm}$ internal diameter, $500 \mathrm{~mm}$ depth and $5 \mathrm{~mm}$ wall thickness. The length of columns was kept the same as $450 \mathrm{~mm}$ for both floating and end-bearing columns. The thickness of soft clay bed of $650 \mathrm{~mm}$ was used for floating column models and $450 \mathrm{~mm}$ soft clay bed thickness was used for end-bearing column models. The summary of the tests has been given in Table 2.

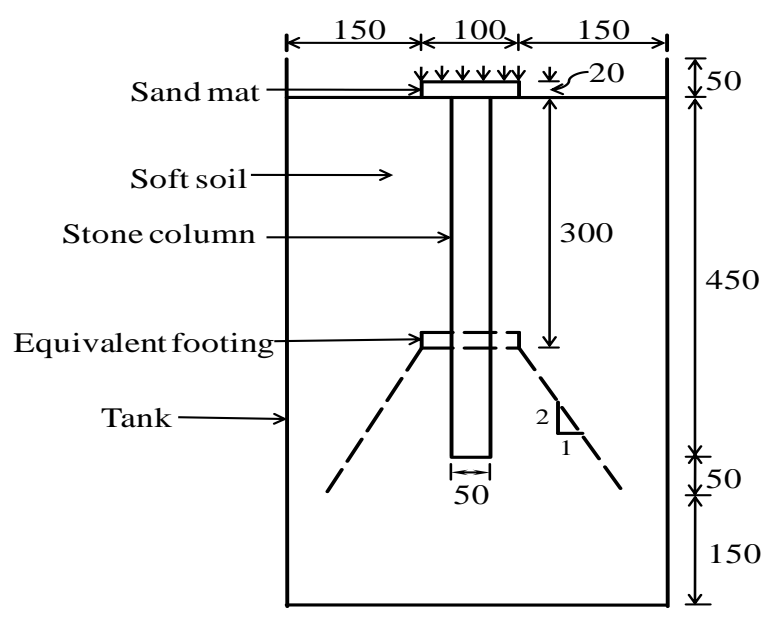

Fig -2: Schematic view of column foundation

\subsection{Preparation of Soft Clay Bed}

The soft clay bed was prepared for undrained shear strength of 6-7 kPa. After adding the required quantity of water to the clay powder it was thoroughly mixed to a consistent paste and then left for 48 hours covered with wet gunny cloth for moisture equalization. This paste was then filled in the tank in $10 \mathrm{~mm}$ thick layers to the desired thickness by hand compaction such that no air voids are left in the soil. Before filling the soil in the tank, the inner surface of the tank wall was first coated with silicon grease and then covered with a polythene sheet to minimize the friction between the tank wall and the soil. The tank filled with soil was then again left for 48 hours for thixotropic gain.
Table -2: Summary of the model tests conducted

\begin{tabular}{|l|l|l|l|l|}
\hline $\begin{array}{l}\text { Test } \\
\text { No. }\end{array}$ & $d(\mathrm{~mm})$ & $l(\mathrm{~mm})$ & ColumnType & $\begin{array}{l}\text { Encasement } \\
\text { Length }\end{array}$ \\
\hline 1. & - & - & Plain Clay & - \\
\hline 2. & 50 & 450 & Floating & Unreinforced \\
\hline 3. & 50 & 450 & Floating & $25 \%$ \\
\hline 4. & 50 & 450 & Floating & $50 \%$ \\
\hline 5. & 50 & 450 & Floating & $75 \%$ \\
\hline 6. & 50 & 450 & Floating & $100 \%$ \\
\hline 7. & 50 & 450 & End-bearing & Unreinforced \\
\hline 8. & 50 & 450 & End-bearing & $25 \%$ \\
\hline 9. & 50 & 450 & End-bearing & $50 \%$ \\
\hline 10. & 50 & 450 & End-bearing & $75 \%$ \\
\hline 11. & 50 & 450 & End-bearing & $100 \%$ \\
\hline
\end{tabular}

\subsection{Construction of Stone Columns}

To construct unreinforced stone column, open-ended perspex pipe of external diameter $=50 \mathrm{~mm}$ and wall thickness $=1 \mathrm{~mm}$ was pushed $15 \mathrm{~mm}$ inside the soft soil bed at centre of the tank diameter. The soil from inside the casing pipes was then taken out with the help of an augur. This pipe was then again pushed into the soil by $15 \mathrm{~mm}$ and the soil was again removed from the pipe. This process was repeated till the casing pipe reached the full column depth. The stone column was then cast in steps, filling and compacting stone chips while simultaneously withdrawing the casing pipe during each step.

To construct a fully encased stone column, after removal of the soil from inside the casing pipe as mentioned above, the casing pipe was first gently pulled out of the soil. A stitched geotextile (Fig. 3a) of required length and diameter was then placed inside the cavity thus formed with the help of a slightly smaller diameter pipe (Fig. 3b) than the diameter of the cavity such that the geotextile stuck to the soil. The stone column was then casted in steps, filling and compacting stone chips. In case of partially encased column, first the unreinforced portion was casted as described earlier and then the encased part was casted similar to fully encased column. The composite soil with the column inside was again left covered with a wet jute fabric in the controlled conditions for 24 hours to develop proper bonding between the stone column and the soft soil. Before loading, a sand mat of $20 \mathrm{~mm}$ thickness was then constructed by pouring Badarpur sand of required gradation over the footing area.

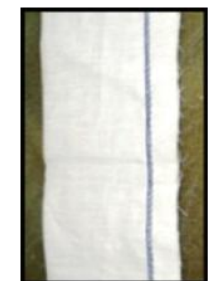

(a)

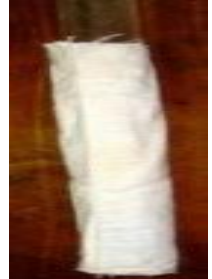

(b)
Fig. 3 (a) Stitched encsement of geotextile (b) Stitched encasement on pipe 


\subsection{Test Procedure}

Load was applied through the $12 \mathrm{~mm}$ thick perspex circular footing having diameter double the diameter of the stone column which represents $25 \%$ area replacement ratio. Models were subjected to strain-controlled compression loading in a conventional loading frame (Fig. 4) at a fast rate of settlement of $1 \mathrm{~mm} / \mathrm{min}$ to ensure undrained condition up to a maximum footing settlement of $90 \mathrm{~mm}$. The applied load on footing was observed by a proving ring at every 1 $\mathrm{mm}$ settlement. Footing pressure or applied vertical stress was calculated by dividing the total load applied on the footing measured by the area of the footing.

\subsection{Post Test Analysis}

After completion of the test, the stone chips from the column were carefully picked up and a thin paste of plaster of Paris was poured into the cavity (Fig. 5) to establish the deformed shape of the column. The hardened plaster of Paris representing the deformed column shape was isolated by removing the surrounding soft soil. Some of the photographs of deformed columns have been shown in Fig. 6.

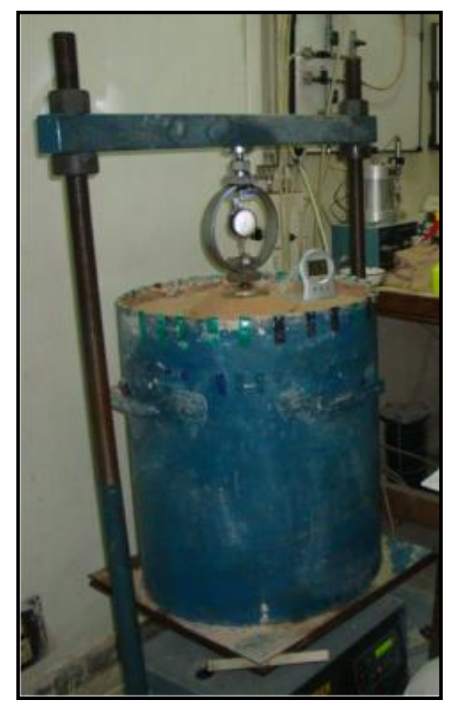

Fig. 4 Test set up ready for loading

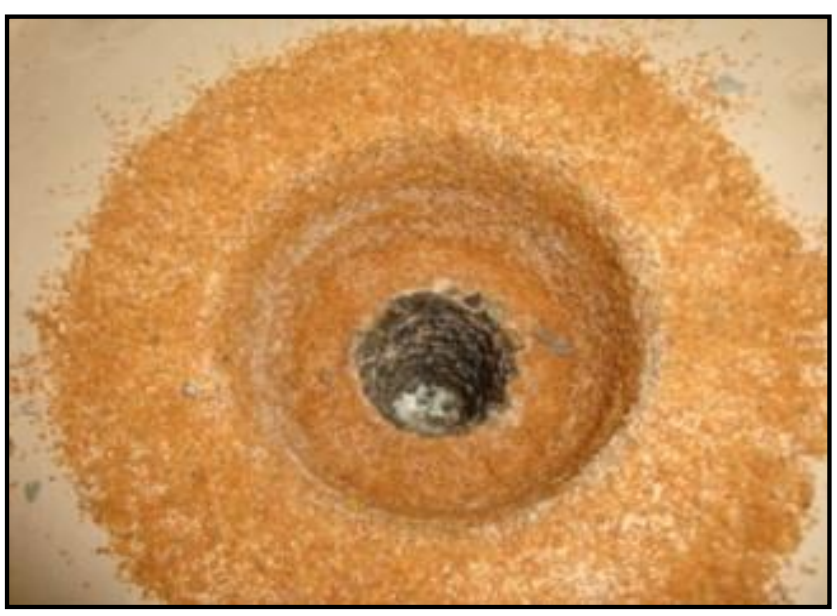

Fig. 5 Cavity formed after removal of stone chips

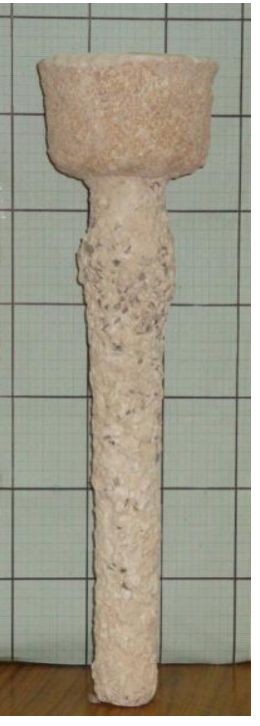

(a)

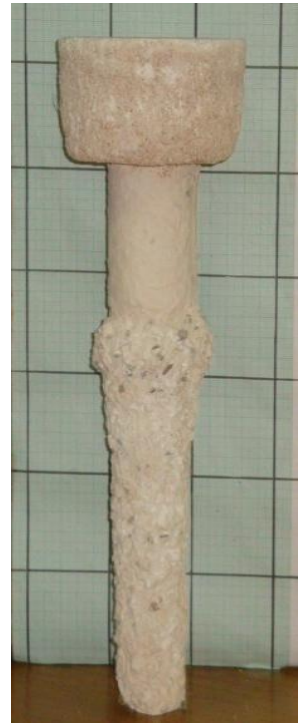

(b)

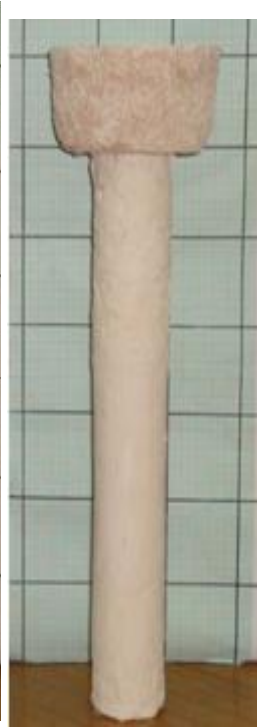

(c)
Fig. 6 Exhumed columns (a) Unreinforced (b) Partially reinforced (c) Fully reinforced

\section{RESULTS}

To study the relative performance of composite soil improved with reinforced stone columns, non-dimensional charts were prepared with the help of normalized applied vertical stress and footing settlement. The applied vertical stress $(\sigma)$ was normalized by dividing it with undrained shear strength $\left(\mathrm{c}_{\mathrm{u}}\right)$ of soft clay bed and footing settlement $(\delta)$ by dividing it with the column length $(l)$. Thus in the ongoing text, the word "failure stress" stands for "normalized failure stress". Figure 7 shows the effect of encasement length on the failure stress of composite ground improved with floating columns and Figure 8 shows the effect of encasement length on the failure stress composite ground improved with end-bearing columns.

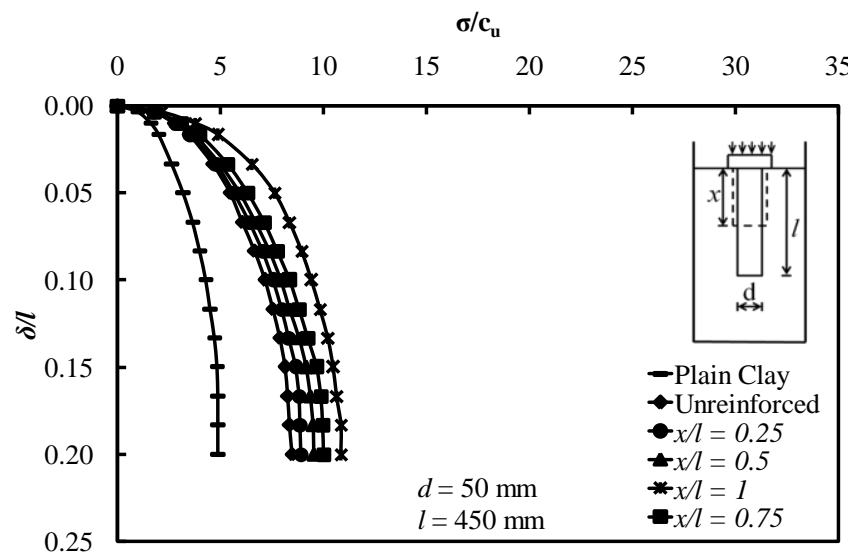

Fig. 7 Effect of encasement for the composite ground improved with floating columns $(d=50 \mathrm{~mm}, l=450 \mathrm{~mm}$, $\left.\mathrm{D}_{\mathrm{r}}=60 \%, \mathrm{~A}_{\mathrm{r}}=25 \%\right)$. 


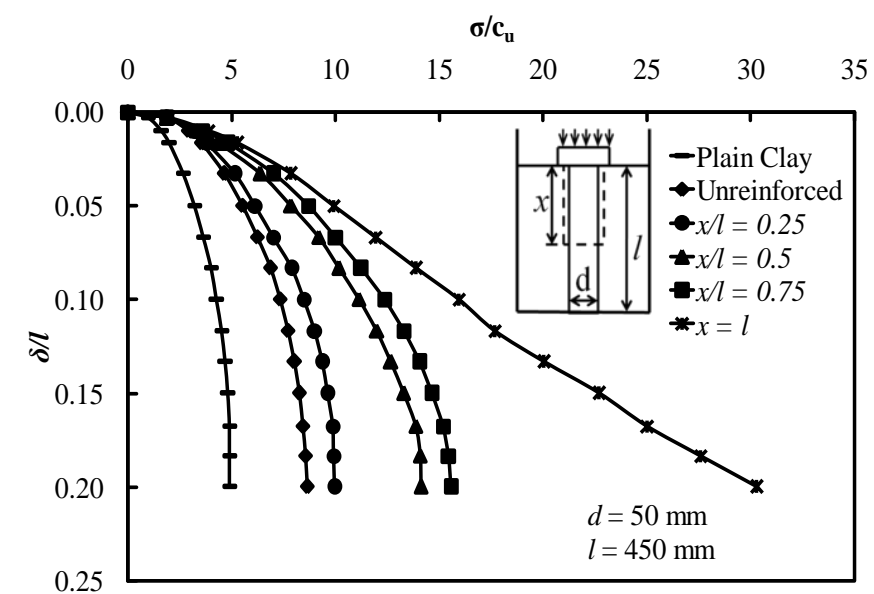

Fig. 8 Effect of encasement for the composite ground improved with end-bearing columns $(d=50 \mathrm{~mm}, l=450$ $\left.\mathrm{mm}, \mathrm{D}_{\mathrm{r}}=60 \%, \mathrm{~A}_{\mathrm{r}}=25 \%\right)$.

\section{DISCUSSION}

Provision of encasement to columns improves the load carrying capacity of composite ground. The composite ground improved with floating or end-bearing columns, the increase in load carrying capacity increases as encasement length increases but the increase is not significant in case of composite ground improved with floating columns. The floating columns encased to their upper $25 \%$ length, the increase in bearing capacity of composite ground was only $5 \%$ more than that of the composite ground improved with unreinforced columns. When the encasement length increased to $50 \%$ and $75 \%$ of the column length, there was an increase of bearing capacity of composite ground by $12 \%$ and $18 \%$ respectively. Fully encased columns could enhance the bearing capacity only by $28 \%$. The encasement increases the stiffness of the columns and upon loading, the insertion of columns take place due to their floating nature and the strength of the reinforcing material is not fully utilized. This is the main cause of poor performance of floating columns.

Similar to floating columns, encasement to $25 \%$ column length of end-bearing columns also could not produce encouraging results. The increase in bearing capacity of composite ground improved with end-bearing columns encased to the upper $25 \%$ column length was only $15 \%$. Encasement length of $50 \%$ and $75 \%$ column length increased the bearing capacity of composite ground by $63 \%$ and $80 \%$ respectively. The bearing capacity of composite ground improved with fully encased end-bearing columns was observed $250 \%$ more than the bearing capacity of composite ground improved with unreinforced end-bearing stone columns. In case of partially encased end-bearing columns, upon loading, the bulging took place at junction of unreinforced and reinforced portion that is why the improvement in bearing capacity is not substantial. In case of fully encased columns, upon loading, hoop stresses are developed in geotextile because there is no scope for bulging as well as penetration of column. The hoop stresses developed in geotextile are responsible for increased load carrying capacity.

\section{CONCLUSIONS}

1. The increase in load carrying capacity of composite ground is directly proportional to encasement length of columns.

2. Hoop stresses developed in column reinforcing material are responsible for increased load carrying capacity of composite ground.

3. Partially encased columns, whether floating or endbearing are not much beneficial.

4. Floating columns even encased to their full lengths could not perform well.

5. The performance of fully encased end-bearing columns was excellent.

\section{REFERENCES}

[1] Priebe, H. J. (1976). Evaluation of the settlement reduction of a foundation improved by VibroReplacement. Bautechnik, 5, (pp. 160-162).

[2] Ranjan, G. (1989). Ground treated with granular piles and its response under load. Indian Geotechnical Journal, 19(1), (pp. 1-86).

[3] Greenwood, D. A. (1970). Mechanical improvement of soils below ground surface, Conference on Ground Engineering, Institution of Civil Engineers, London, (pp. 11-22).

[4] Malarvizhi, S. N., \& Ilamparuthi, K. (2004). Load versus Settlement of Clay bed stabilized with Stone \& Reinforced Stone Columns. 3rd Asian Regional Conference on Geosynthetics, Seoul, (pp. 322-329).

[5] Ayadat, T., \& Hanna, A. M. (2005). Encapsulated Stone Columns as a Soil Improvement Technique for Collapsible Soil. Ground Improvement, 9 (4), (pp. 137-147).

[6] Murugesan, M., \& Rajagopal, K. (2010). Studies on the Behaviour of Single and Group of Geosynthetic Encased Stone Columns. Journal of Geotechnical and Geo-environmental Engineering, 136 (1), (pp. 129-139). 